\title{
Water erosion vulnerability and sediment delivery rate in upper Iguaçu river basin - Paraná
}

\section{Vulnerabilidade à erosão hídrica e taxa de aporte de sedimentos na Bacia Hidrográfica do Alto Rio Iguaçu - PR}

\author{
Matheus Fonseca Durães ${ }^{1}$, José Alexandre Pinto Coelho Filho ${ }^{2}$ and Vinícius Augusto de Oliveira \\ ${ }^{1}$ Universidade Federal do Paraná, Curitiba, PR, Brasil \\ ${ }^{2}$ Serviço Geológico do Brasil, Goiânia, GO, Brasil \\ ${ }^{3}$ Universidade Federal de Lavras, Lavras, MG, Brasil \\ E-mails: duraes@ufpr.br (MFD), alexandre.coelho@cprm.gov.br(JAPCF), aovinicius@gmail.com (VAO)
}

Received: February 24, 2016 - Revised: May 19, 2016 - Accepted: June 30, 2016

\begin{abstract}
Soil erosion is one of the most striking environmental degradation processes, which its mapping and assessment is an important tool for management activities and natural resource management in river basins, allowing managers to implement policies and sustainable land use occupation. This work aimed to apply the Revised Universal Soil Loss Equation (RUSLE) in a GIS environment in the upper Iguaçu river basin, located at Paraná State, in order to assess the vulnerability to water erosion as well as the concentration of dissolved solids in suspension to estimate the solid discharge and sediment delivery rate, allowing the identification of more susceptible areas to water erosion. The results showed that over $23.52 \%$ of the upper Iguaçu river basin presented soil losses below $2.5 \mathrm{t} \mathrm{ha}^{-1} \mathrm{yr}^{-1}$, meaning current low potential for erosion. Regarding the solid discharge, the basin has values ranging from low to very high, also leading to high values for sediment delivery rate. The identification of risk areas associated with accelerated erosion, carried out in this study provide important information for measures associated with the management, conservation and planning of land use in the basin, which is highly relevant for predicting development of various scenarios for the state Paraná for its hydroelectric potential.
\end{abstract}

Keywords: Soils; Geoprocessing; RUSLE.

\section{RESUMO}

A erosão do solo é um dos processos de degradação ambiental mais impactantes, no qual seu mapeamento e avaliação consiste em uma importante ferramenta para atividades de manejo e gestão dos recursos naturais em bacias hidrográficas, permitindo aos gestores implementar políticas de uso e ocupação do solo de forma sustentável. O presente trabalho teve por objetivo a aplicação da Equação Universal de Perda de Solo Revisada (RUSLE) em ambiente SIG, na Bacia Hidrográfica do Alto Rio Iguaçu (BHARI), localizada no Estado do Paraná / Brasil, afim de avaliar a vulnerabilidade à erosão hídrica bem como a concentração dos sólidos dissolvidos em suspensão para estimar a descarga solida e a taxa de aporte de sedimentos, permitindo identificar áreas mais suscetíveis à erosão hídrica. Os resultados mostraram que mais de $23,52 \%$ da BHARI apresentou perdas de solo abaixo de $2,5 \mathrm{t} \mathrm{ha}^{-1}$ ano $^{-1}$, significando baixo potencial atual de erosão. Em relação a descarga sólida, a bacia apresentou valores variando de baixo a muito alta, levando também a elevados valores para a taxa de aporte de sedimentos. A identificação de áreas de risco associadas à erosão acelerada, realizadas neste estudo, fornecem subsídios importantes para medidas associadas ao manejo, conservação e planejamento do uso do solo nesta bacia, a qual é altamente relevante para predição de desenvolvimento de cenários variados para o Estado do Paraná por seu potencial hidroelétrico.

Palavras-chave: Solos; Geoprocessamento; RUSLE. 


\section{INTRODUCTION}

Accelerated soil erosion has been widely recognized as an environmental problem related to the use of soil for agricultural and forest-based practices. This affects soil's productive capacity, causing a reduction in its porosity as well as retention capacity and water infiltration, resulting in an increase of surface runoff, from the transportation of sediments and the aggradation of water resources.

As a result, changes in soil coverage, biomass and the hydrological regime in basins tend to occur, affecting the erosion process, as Lee and Lee (2010) and Mello et al. (2015) have suggested, possibly causing alterations in the fluvial geomorphology (GUERRERO et al., 2013).

According to Pandey, Chowdary and Mal (2007), in order to adequately manage a drainage basin, with a goal of natural resource sustainability, it is necessary to have specialized information about the erosion potential of the soil and the production as well as the transportation of sediments. However, modeling the soil erosion process is a complex task due to the diverse interactions that occur among both the active and passive factors influencing the process.

Still, the quantitative evaluation of erosion can contribute to the preparation of possible strategies for drainage basin management in the context of sustainable development. So, in this manner, erosion simulation models, especially distributed models, are useful to evaluate different strategies of soil usage and better the management of soil in drainage basins (BESKOW et al., 2009).

In this context, many efforts have been made to develop and improve models to predict soil loss, which varies from empirical equations like the Universal Soil Loss Equation (USLE) (WISCHMEIER; SMITH, 1978) and its revised version (RUSLE) (RENARD et al., 1991), up to the most sophisticated models, such as the Water Erosion Prediction Project (WEPP) (NEARING; LANE; LOPES, 1994), currently geo-WEPP and SWAT (ARNOLD et al., 1998; GASSMAN et al., 2007). The latter can be physically more efficient than the empirical models but they usually need a high amount of input data, for which, information is frequently not readily available. Furthermore, they are computationally more rigorous, particularly in reference to the soil erosion potential on a medium to large scale, such as in a large drainage basin (WANG et al., 2009).

On the other hand, RUSLE has been extensively used on different scales, principally for the simplicity of its formulation (HUI et al., 2010; WANG et al., 2009). Its evaluation results from many factors that influence the erosive process, which are: rainfall erosivity $(\mathrm{R})$; soil erodibility $(\mathrm{K})$; usage and management of the soil (C); conservational practices (P) and topography (LS), the lastmentioned represented by slope length effects (L) and declivity (S). These characteristics, especially the calculation manner of the LS factor incorporated into the model, allows the application of RUSLE on a large scale (DURÃES; MELLO, 2014).

As all equation factors are able to be specialized, it has been common to use geoprocessing in the evaluation of soil erosion vulnerability. So, in this manner, the tools associated with a Geographical Information System (GIS) can facilitate the the acquisition of topographical factors through derivation of a digital elevation model (DEM), as demonstrated by Wang et al. (2009). With the use of GIS, the complexity of a drainage basin can be understood through its discretization in smaller and more homogenous units, facilitating the understanding of the erosion process.

The Upper Iguaçu River Basin (UIRB) makes up part of a fundamental planning and environmental management unit in the state of Paraná, draining directly to the Itaipu reservoir. In this sense, it is of extreme importance that studies of this nature be developed with the purpose of subsidizing the handling, management, and the use of natural resources due to the strategic importance of this drainage basin for the economy of the state of Paraná and even Brazil, due its hydroelectric potential.

For this reason, the objectives of this work were: to determine the current potential of the soil to suffer water erosion, applying the Revised Universal Soil Loss Equation (RUSLE); to estimate the annual average of solid discharge by way of the hydrosedimentological rating curves; and sediment delivery rate based on the relation between gross water erosion and solid discharge for the studied points

\section{MATERIAL AND METHODS}

\section{Study area and its description}

The UIRB, with a drainage area of $2,740 \mathrm{~km}^{2}$, is a tributary of the Iguaçu river that flows into the Paraná River. The basin is located between the geographic coordinates $25^{\circ} 13^{\prime} 48^{\prime \prime}$ and $25^{\circ} 49^{\prime} 48^{\prime \prime}$ south latitude and $48^{\circ} 57^{\prime} 36^{\prime \prime}$ and $49^{\circ} 41^{\prime} 24^{\prime \prime}$ west longitude. The UIRB includes 26 subbasins, with a mainly flat relief, featuring a great area of natural dale on both banks and forming well-defined floodplains (KNAPIK et al., 2011). The climatic classification of the basin according to the Köppen method is the Humid Subtropical Climate type (Cfb), with hot summers and mild winters and no dry season. The UIRB has its meteorological and atmospheric dynamic conditions influenced by the polar and tropical air masses, with annual average precipitation at 1,500 mm according to Silva, Lermen and Nery (2001) and with average temperature varying from $12.9^{\circ} \mathrm{C}$ in the coldest month to $22.5^{\circ} \mathrm{C}$ in the hottest month, with annual average of $16.4^{\circ} \mathrm{C}$. Figure 1 shows the location of the said drainage basin in the state of Paraná.

According to the basemap from SUDERHSA (2004), the predominant soils in the basin are the Latosols (42.76\%), Argisols (23.47\%), Cambisols (12.71\%), Gleysols (11.28\%), Orgonosol (7.29\%), Litholic Neosol (2.26\%) and Fluvic Neosol (0.23\%). The distribution percentage of each class of soil usage on the UIRB, shown on Table 1, was obtained by satellite imaging from LANDSAT 8 in 2012 with a $30 \mathrm{~m}$ resolution. The soils map and soil usage and coverage map can be found in Figure 2a and 2b, respectively.

Table 1. Percentage distribution of the soil types in UIRB.

\begin{tabular}{lccc}
\hline \multicolumn{1}{c}{ Soil Use } & Area (\%) & Soil Use & Area (\%) \\
\hline Outcrops & 0.43 & Forestry & 4.71 \\
Water & 17.68 & Mining & 0.47 \\
Wetland & 1.45 & Bare Soil & 1.04 \\
Grassland & 22.42 & Urbanization & 14.24 \\
Perennial Crop & 0.16 & Annual Crop & 8.11 \\
Native Forest & 19.94 & Shrubby & 9.35 \\
\hline
\end{tabular}




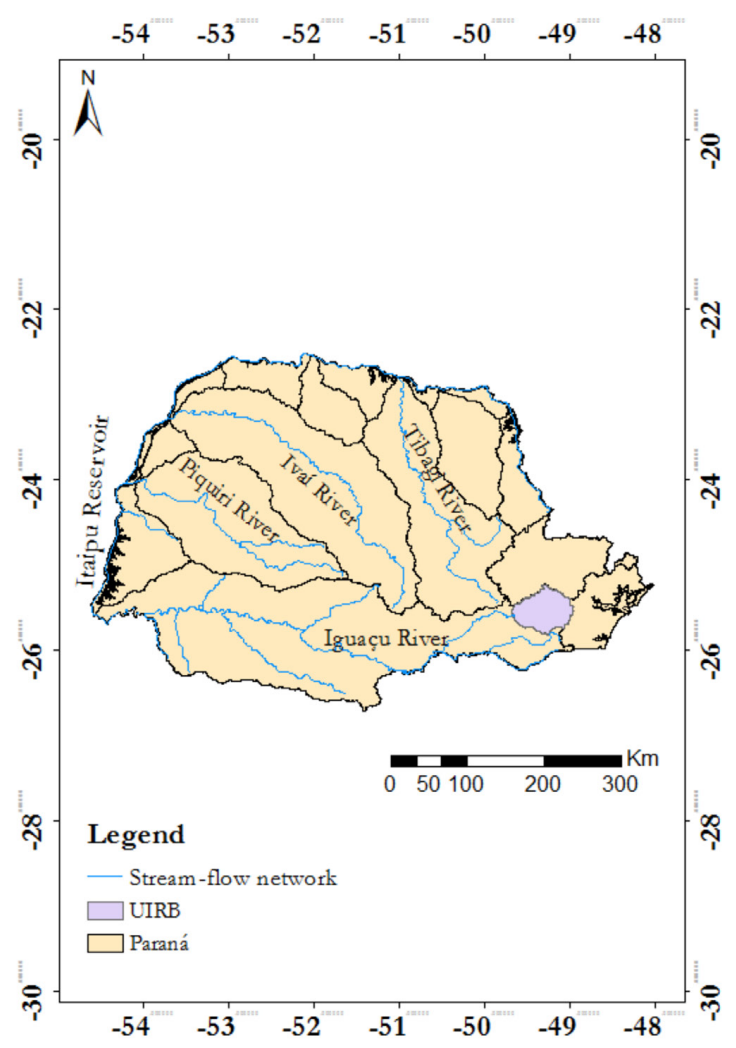

Figure 1. Map of the location of the UIRB in the state of Paraná.

\section{Sediment yield}

In order to describe sediment production in the UIRB, monitored sedimentometric data is implemented and made available within the National Water Agency's (Agência Nacional das Águas or ANA) hydrometeorological network. This data allows for the creation of the hydrosedimentological rating curve via the relation between the concentration of solids in suspension and the respective discharge at a given flow measuring section. The daily sediment load, designated as solid discharge (Qss) is, therefore, estimated in relation to the average concentration of solids in suspension and the section's discharge.

The locations used to acquire the rating curve correspond, as well, to the flow measuring and sedimentometric stations, that is to say, for every location there is a history of discharge and solids in suspension. The locations P1, P2, P3, P4, P5, P6 and P7 define the limits of the subbasins sub-1, sub-2, sub-3, sub-4, sub-5, sub-6 and sub-7, respectively. This information is presented in Table 2 and the spatial distribution of the stations is presented in Figure 3.

\section{Application of the RUSLE to the UIRB}

In order to characterize the erosion process, it is necessary to analyze the elements of the physical environment that take part in this process. This means that it is essential when working in large areas, to utilize a system in which it is possible to promote a spatial interaction among the data, this process being known

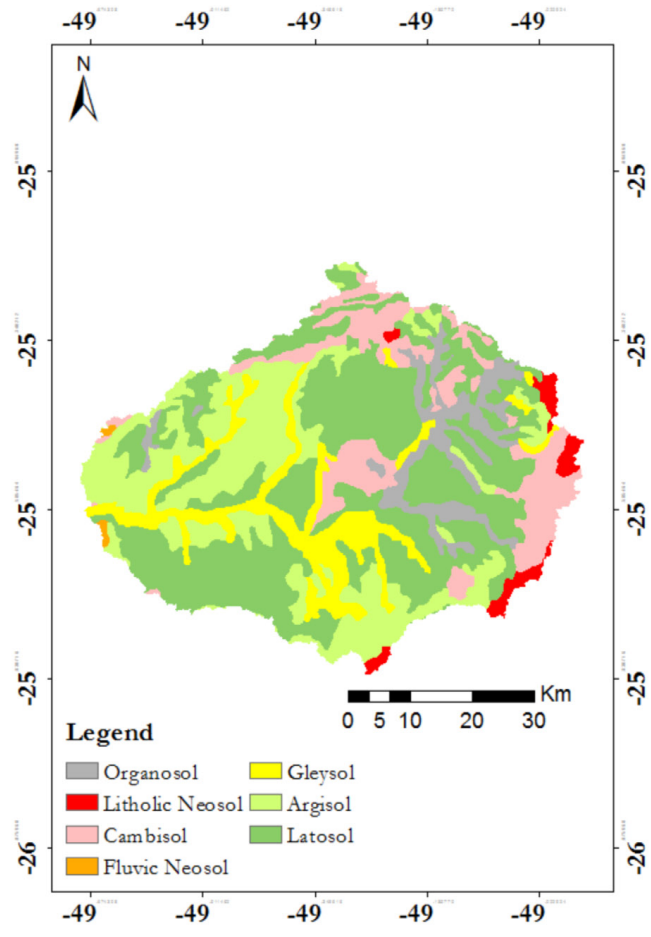

(a)

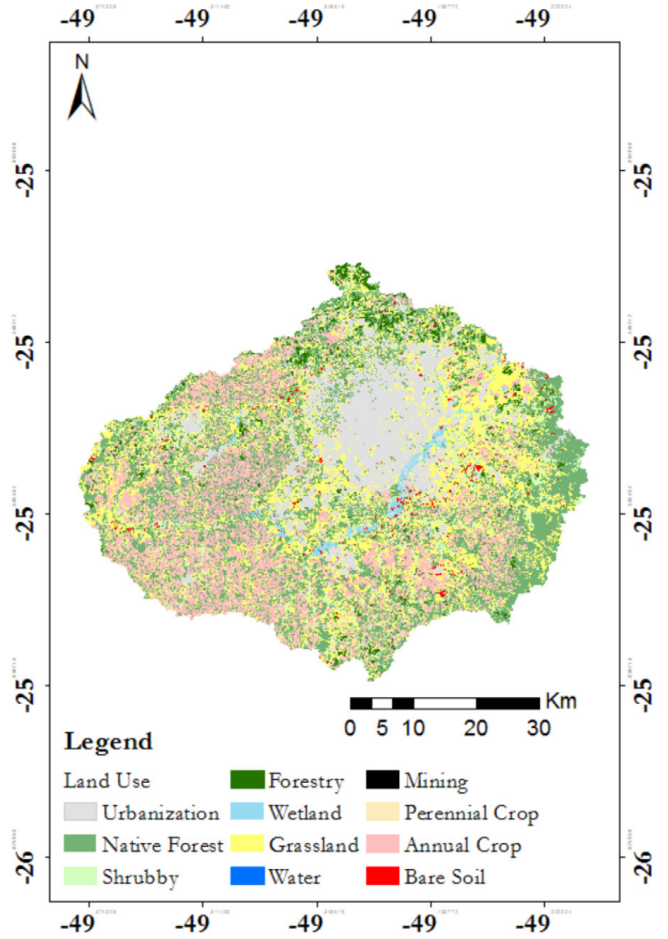

(b)

Figure 2. UIRB soil map (a) and soil usage and coverage map (b). 


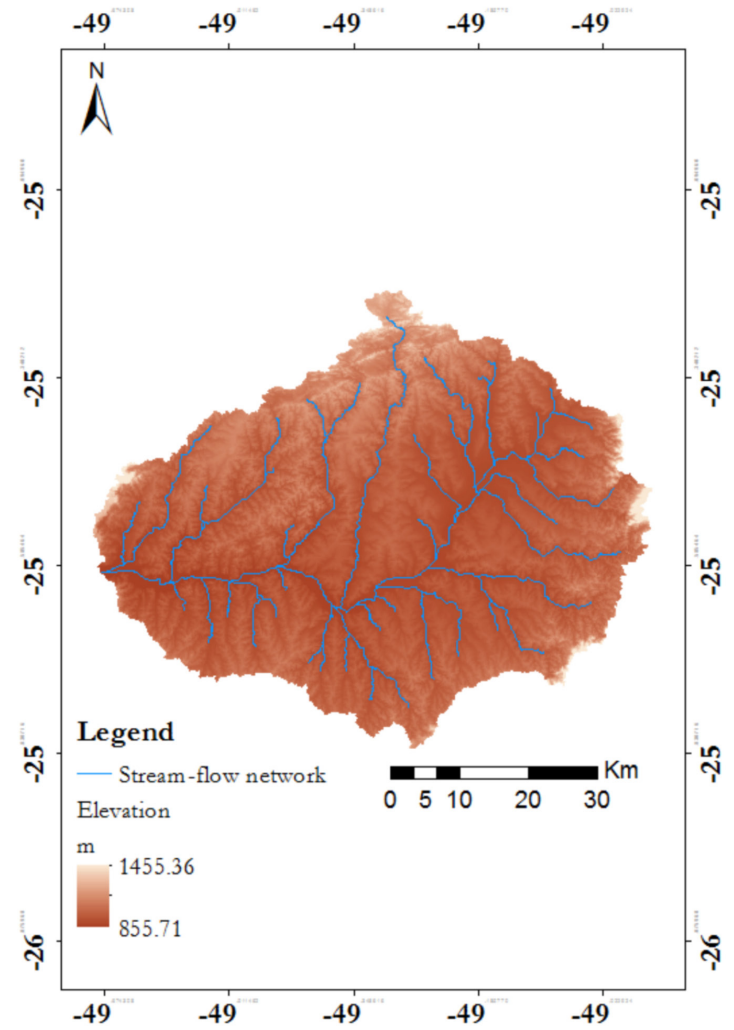

a)

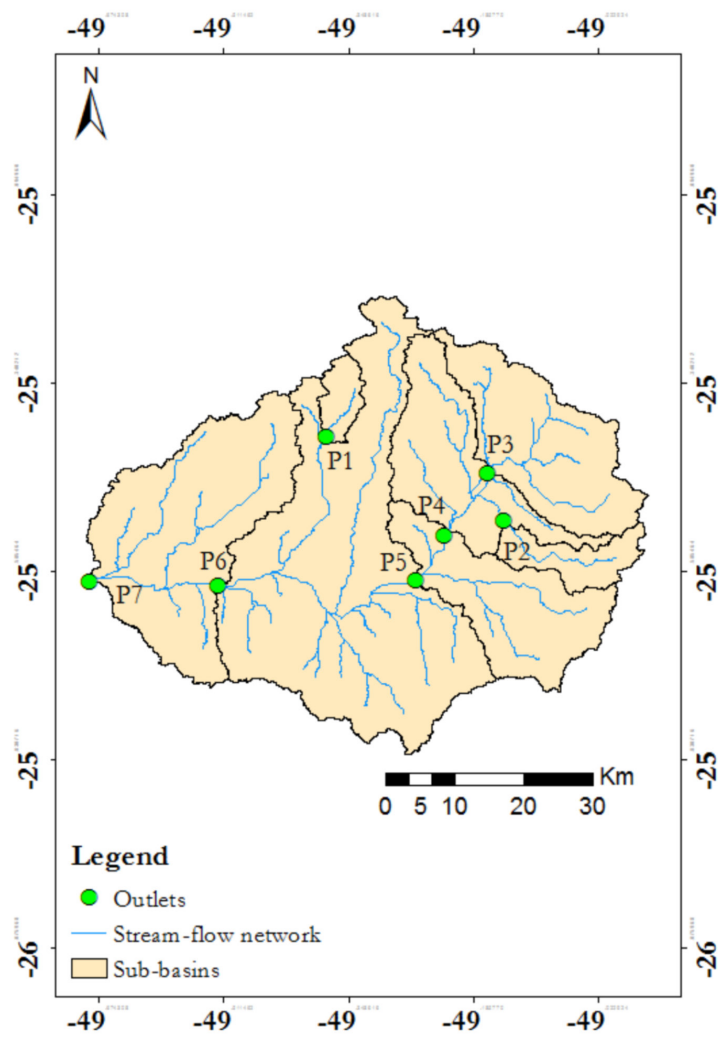

b)

Figure 3. Digital Elevation Model (a) and flow measuring/sedimentometric location (b).

Table 2. Main data for the utilized stations.

\begin{tabular}{ccccc}
\hline Outlet & $\begin{array}{c}\text { ANA } \\
\text { Code }\end{array}$ & $\begin{array}{c}\text { South } \\
\text { Latitude }\end{array}$ & $\begin{array}{c}\text { West } \\
\text { Latitude }\end{array}$ & Series \\
\hline P1 & 65021000 & 25.3547 & 49.3547 & $2001-09$ \\
P2 & 65010000 & 25.5191 & 49.1466 & $2002-05$ \\
P3 & 65006075 & 25.4538 & 49.1714 & $2001-10$ \\
P4 & 65013005 & 25.5280 & 49.2188 & $1984-10$ \\
P5 & 65017006 & 25.5986 & 49.2592 & $1993-10$ \\
P6 & 65025000 & 25.6003 & 49.5133 & $1994-10$ \\
P7 & 65028000 & 25.5886 & 49.6319 & $2002-08$ \\
\hline
\end{tabular}

as Map Algebra. This study has chosen the RUSLE model and applied it with support of SIG ArcMap ${ }^{\circledR}$ (ESRI, 2004). This model is part of the refinement of the USLE developed by Renard et al. (1991) envisioning its application to scale on drainage basins, stemming from an adjustment of the topographical LS-factor, represented in Equation 1.

$$
\mathrm{A}=\mathrm{R} \cdot \mathrm{K} \cdot \mathrm{L} \cdot \mathrm{S} \cdot \mathrm{C} \cdot \mathrm{P}
$$

where: A represents the annual amount of soil loss $\left(\mathrm{t} \mathrm{ha}^{-1} \mathrm{yr}^{-1}\right)$; $\mathrm{R}$ is the rainfall erosivity variable $\left(\mathrm{MJ} \mathrm{mm} \mathrm{ha} \mathrm{ma}^{-1} \mathrm{hr}^{-1}\right)$; $\mathrm{K}$ is the erodibility variable of the soils $\left(\mathrm{t} \mathrm{h} \mathrm{MJ}^{-1} \mathrm{~mm}^{-1}\right)$; $\mathrm{L}$ is the length of the slope; $\mathrm{S}$ is the declivity variable; $\mathrm{C}$ is the the soil coverage variable and $\mathrm{P}$ is the conservational practices variable.
$\mathrm{R}$-factor represents the potential of natural rain to cause soil erosion, whose physical definition consists of the kinetic energy of rain with an intensity of up to 30 consecutive minutes (WISCHMEIER; SMITH, 1978). For an estimation of annual average erosivity based on spatial distribution, with an aim to arrange the Map Algebra more precisely, this study has utilized a geographical and statistical model developed by Mello et al. (2013).

The K-factor represents the intrinsic vulnerability to erosion, that is to say, the ease with which soil particles are displaced by the impact of raindrops. The values of $\mathrm{K}$ utilized and the respective citations are presented in Table 3.

In light of the existing limitations of the conception of the topographical variable, Moore and Burch (1986) proposed a theoretical basis for determining this variable, which is based on Yang's (1984) unit stream power theory. This theory demonstrates that water on the surface of soil presents a certain amount of energy which is capable of disaggregating and transporting the solid particles, moving them in the direction of the slope and, in turn, representing the LS-factor in complex relief areas, such as is the case with drainage basins, once the model of the specific contribution area has been considered.

In the case of RUSLE, the LS-factor incorporates an important concept associated with the contribution of runoff from upstream cells to downstream ones, embodying a physical 
significance that is more appropriate to the erosion process than the formulation proposed by Wischmeier and Smith (1978). In this study, the LS-factor calculation procedure proposed by Moore and Burch (1986) was used and applied via the Raster Calculator Tool from the program ArcGIS, being represented by the equation below (ZHANG et al., 2013):

$$
\mathrm{LS}=(\mathrm{FA} \times(\mathrm{CS} / 22,13))^{0,4} \times(\operatorname{sen}(\mathrm{S}) / 0,0896)^{1,3}
$$

where: FA is the flow accumulation from the contribution área; CS is the DEM cell size, corresponding to $30 \mathrm{~m}$ of spatial resolution and $\mathrm{S}$ is the declivity in radians calculated for each DEM.

In accordance with Wischmeier and Smith (1978), the $\mathrm{P}$ variable represents cultural practices that can contribute to soil erosion management. As monitoring soil management and conservational practices are difficult to achieve via satellite imaging, since they represent a small portion of the basin, this variable was considered to be 1. It must be highlighted that this same thought was used in various works, such as those of Pradhan et al. (2012), Vemu and Pinnamaneni (2011), Silva, Montenegro and Santos (2012), Oliveira et al. (2014) and Durães, Mello and Beskow (2016). The values of $\mathrm{C}$ used in this study were obtained from the literature presented in Table 4.

\section{Sediment Delivery Rate (SDR)}

In order to determine the SDR in the UIRB, the concept presented by Walling (1983) was first used. It defines SDR as the relation between the transported sediment in the basin control section (average value calculated from a history of discharges)

Table 3. Soil Erodibility classes occuring in the UIRB.

\begin{tabular}{lcc}
\hline \multicolumn{1}{c}{ Soil } & $\left.\mathbf{K ~ ( t ~ h ~} \mathbf{~ M ~ J}^{\mathbf{- 1}} \mathbf{~ m m}^{-1}\right)$ & Source \\
\hline Argisol & 0.033 & Sá et al. (2004) \\
Fluvic Neosol & 0.042 & Ribeiro and Alves (2008) \\
Cambisol & 0.0508 & $\begin{array}{c}\text { Araújo, Salviano and } \\
\text { Holanda Neto (2011) }\end{array}$ \\
Latosol & 0.0191 & Mannigel et al. (2002) \\
Litholic Neosol & 0.0569 & Castro et al. (2011) \\
Organosol & 0.061 & Silva and Alvares (2005) \\
Gleysol & 0.0362 & Batalha (2006) \\
\hline
\end{tabular}

Table 4. CP-Factor for soil coverage and usage conditions.

\begin{tabular}{lcc}
\hline \multicolumn{1}{c}{ Land Cover } & CP-Factor & Source \\
\hline Outcrops & 0 & - \\
Water & 0 & - \\
Wetland & 0.01 & Borges et al. (2012) \\
Grassland & 0.025 & Silva (2004) \\
Perennial Crop & 0.25 & Bertoni and Lombardi Neto (2005) \\
Native Forest & 0.00013 & Martins et al. (2010) \\
Forestry & 0.0026 & Martins et al. (2010) \\
Mining & 1 & - \\
Bare Soil & 1 & - \\
Urbanization & 0 & - \\
Annual Crop & 0.29 & Ruhoff et al. (2006) \\
Shrubby & 0.0015 & Xavier, Silva and Silva (2013) \\
\hline
\end{tabular}

and the average potential erosion considering the entire basin area, being configured as dimensionless and expressed in the following manner:

$\mathrm{SDR}=\mathrm{Y} / \mathrm{E}$

in which: $Y$ represents sediment transportation, also called average sediment production $\left(\mathrm{t} \mathrm{ha}^{-1} \mathrm{yr}^{-1}\right)$, determined in the control section of the water basin; and $\mathrm{E}$ is the average potential water erosion $\left(\mathrm{t} \mathrm{ha}^{-1} \mathrm{yr}^{-1}\right)$.

To estimate the sediment production in the basin and consequently its delivery rate, it is necessary to first determine the rating curve of discharge based on the data monitored at the UIRB (Table 2), enabling the calculation of the sediment transported through the rating curve. Equations 4, 5, 6, 7, 8, 9 and 10, for the locations P1, P2, P3, P4, P5, P6 and P7, respectively, enable the calculation of the sediment transported through the rating curve (Figure 4).

$$
\begin{array}{ll}
\hat{y}=15.91 x^{1.0792} & R^{2}=0.79 \\
\hat{y}=5.0529 x^{0.999} & R^{2}=0.81 \\
\hat{y}=8.1869 x^{0.9848} & R^{2}=0.77 \\
\hat{y}=17.006 x^{0.9704} & R^{2}=0.87 \\
\hat{y}=18.312 x^{0.8866} & R^{2}=0.77 \\
\hat{y}=23.483 x^{0.8014} & R^{2}=0.63 \\
\hat{y}=4.0183 x^{1.0841} & R^{2}=0.87
\end{array}
$$

\section{RESULTS AND DISCUSSION}

Figure 5 presents the annual average rain erosivity (R-factor) at the UIRB. It can be observed on the figure that the values range from 5,243 to $6,735 \mathrm{MJ} \mathrm{mm} \mathrm{ha-1} \mathrm{yr}^{-1}$, the lowest values being found at the highest altitude areas of the basin. This pattern reaffirms the results found by Mello et al. (2013), in which erosivity presents a pattern inversely proportional to the altitude in some parts of the southern region of Brazil. Furthermore, studies developed by Hoyos, Waylen and Jaramillo (2005) in the Colombian Andes region and Nel, Reynhardt and Summer (2010), in South Africa, showed the same pattern seen in the present study.

According to the authors mentioned above, this pattern can be explained by the formation of convective rains, which causes high intensity and short duration precipitation before the clouds reach elevated altitudes, preventing the formation of orographic rains. However, this situation differs from those found by Durães and Mello (2014) and Oliveira et al. (2014), who used the same technique for estimating erosivity, observing that the greatest values 

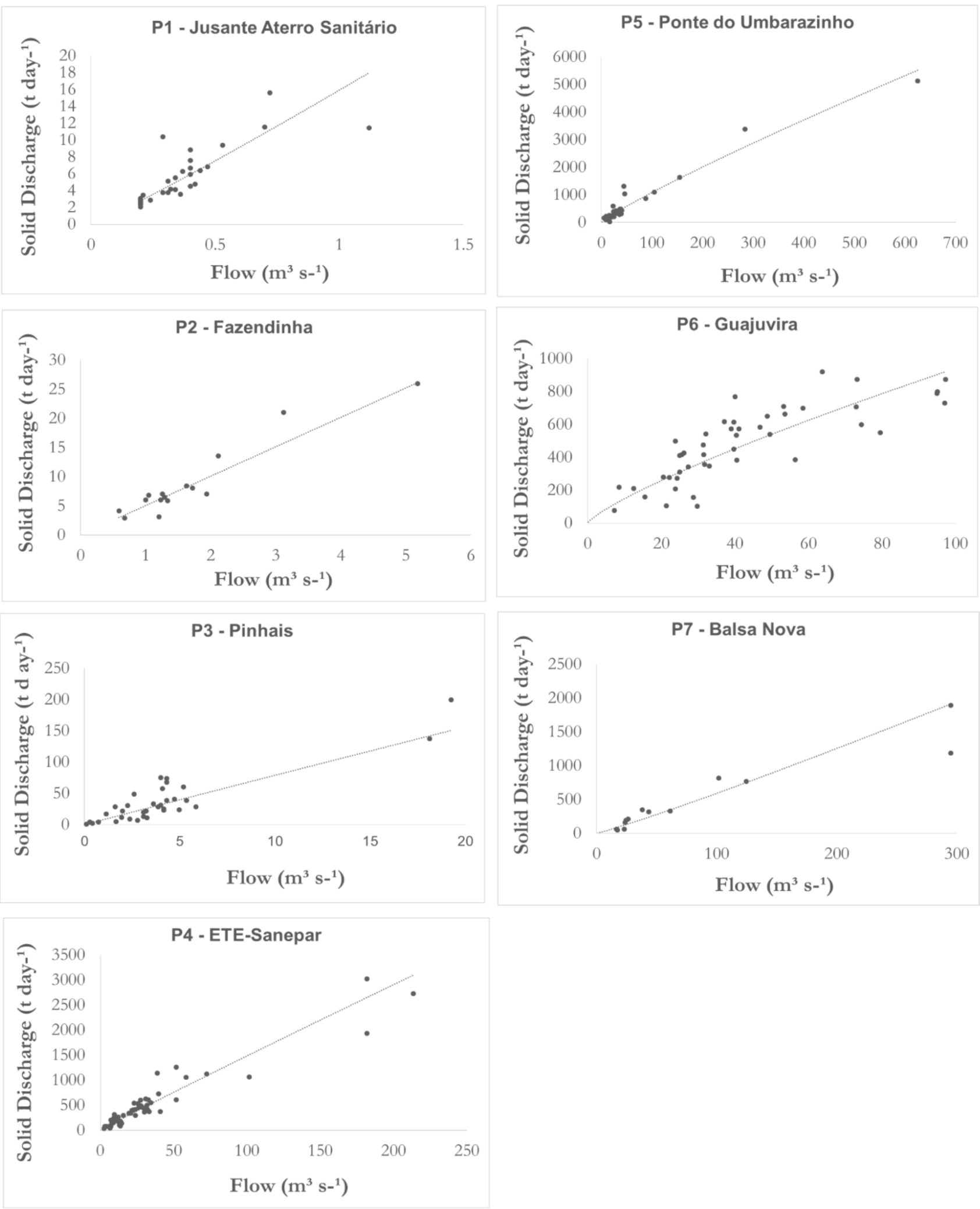

Figure 4. Analyses of the stations' sedimentological rating curves. 
were concentrated at the head of the studied basins, showing that the orographical effect is fundamental to the erosive rains pattern. According to the authors, such features can be attributed to the different characteristics and phenomena inherent to the process of rain formation in each region (south and southeast).
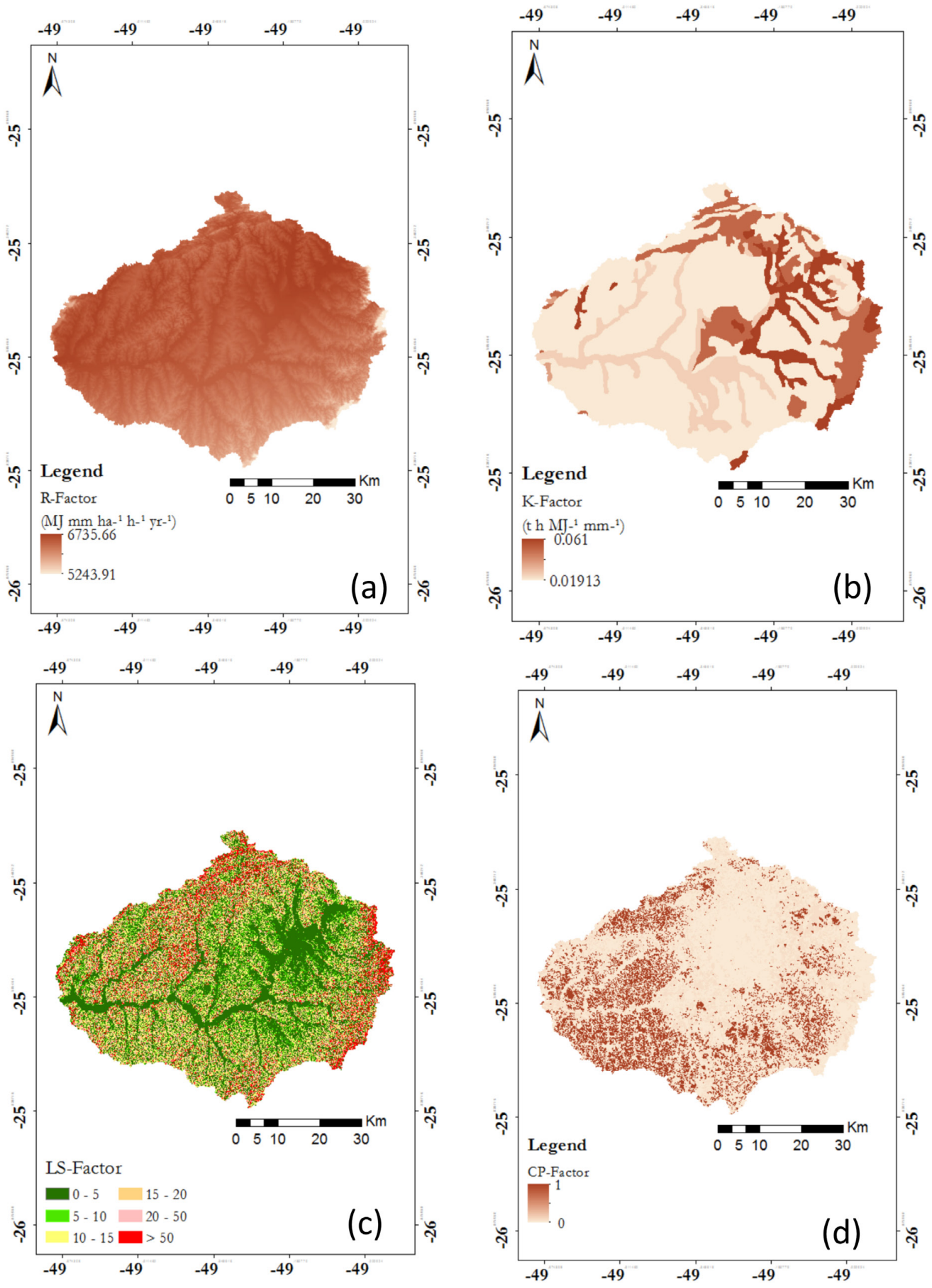

Figure 5. RUSLE variables map: (a) R-factor; (b) K-factor; (c) LS-factor and (d) CP-factor. 
of Marques et al. (1997), Mannigel et al. (2002) and Silva et al. (2009). This variation in the results of erodibility in one single soil type demonstrates that this variable represents diverse meanings within the same class, which, in some ways, makes its acquisition not viable via field sampling for areas as extensive as the basin that was analyzed. Likewise, the adoption of values from the literature, to represent erodibility of the predominant soil classes in large basins, becomes viable and applicable.

The spatial distribution of the LS-factor is presented in Figure $5 \mathrm{c}$. Note that $69.49 \%$ of the basin shows values of less than 10 , representing a low vulnerability associated with the topographical effect. Conversely, $30.51 \%$ of areas show high erosion potential, especially in the areas at the head, which represent greater slopes. Additionally, it is important to consider that the lower values are distributed among areas of lower altitude, while the higher values are found in areas of higher altitude. Such results, utilizing the methodology proposed for the calculation of the LS variable, based on Moore and Burch (1986), are more significant when compared to other methods, since it allows the determination of the existing breakage among basin relief units, providing this variable along the slopes.

The spatial distribution of water erosion vulnerability as estimated using RUSLE, is presented in Figure 6, was adapted to conform to the classification proposed by Beskow et al. (2009), and was also applied in the works performed by Durães and

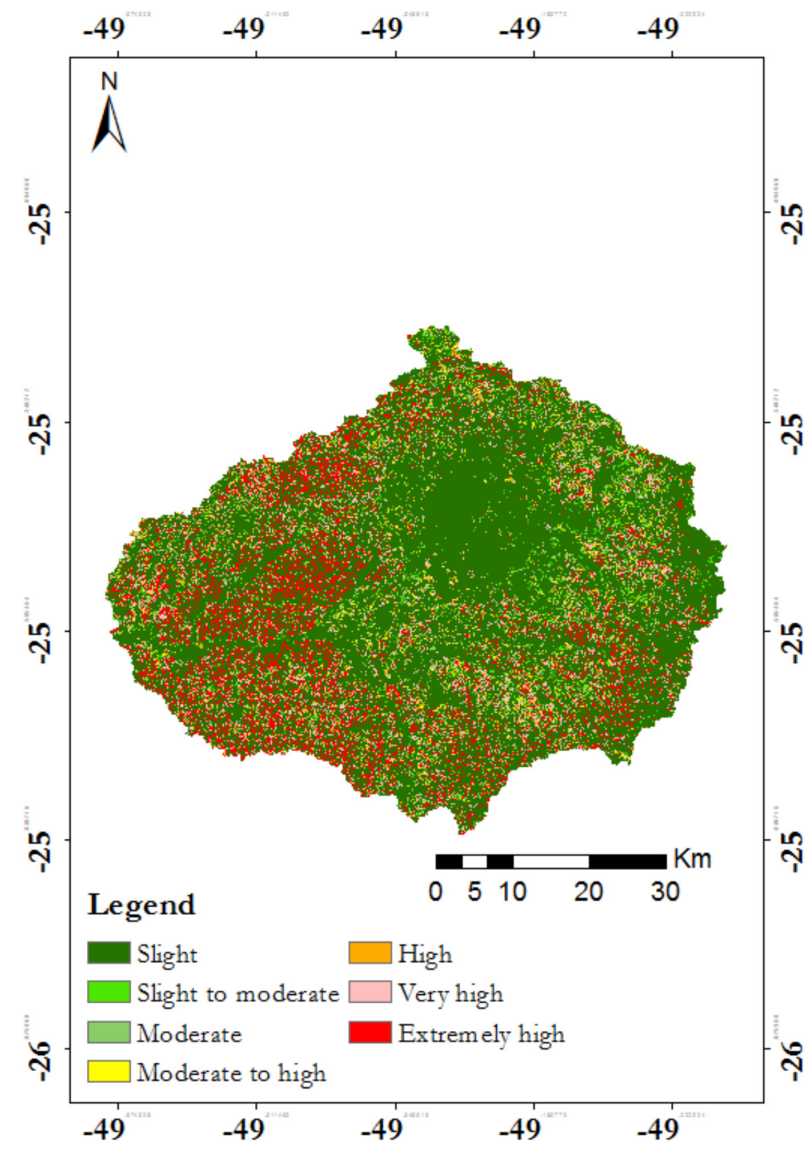

Figure 6. Map of potential water erosion in the UIRB.
Mello (2014) and Oliveira et al. (2014). This type of classification allows a qualitative grouping of water erosion vulnerability into classifications that range from Light to Extremely High. Table 5 shows the distribution of soil erosion classes in the UIRB according to the classification proposal of Beskow et al. (2009).

It is important to mention that the previous interaction of the variables described in RUSLE concerning the type of vegetation is important, due to the fact that it helps in the understanding of areas that are more vulnerable to water erosion.

The stratification of potential soil loss using Map Algebra via SIG, allows the analysis of impact an activity may have on soil erosion behavior in a determined area of a drainage basin. In agricultural areas, this technique results in a more refined application of erosion management techniques, thereby reducing the pressure on management systems that have been adopted.

The innovation presented in this study, supported by techniques that have already been conceptualized, consists of the application of the multivariate model for estimating the -factor, which was spatially distributed across a resolution of 30 meters. It bears mentioning that the model developed by Mello et al. (2013), showed high accuracy once it was adjusted and tested with a robust set of rainfall erosivity data.

It can be observed that areas with a sharp slope, higher altitudes and forest cover have shown soils with lower vulnerability, demonstrating the importance of vegetational cover for soil protection against the effects of erosion agents.

In this sense, Avanzi et al. (2013), who analyzed the process of water erosion in an afforested basin, noticed that in areas intended for planting eucalyptus there is evidence of greater levels of soil loss than in areas with Atlantic Forest vegetation, which reinforces the role of native cover in soil conservation.

The results presented in Table 6 refer to the variation in soil loss for each tolerance classification in the subbasins (Figure 3 and Table 2) and also show the respective pedological unit.

It can be noticed in the figure that the higher rates of soil loss can be associated with the combination of Argisols covered by annual crops. The losses of soil within the Cambisol and Gleysol classifications can mostly be traced to the presence of exposed soil, fields and perennial crops. It is also important to observe that the Litholic Neosol unit showed lower soil loss rates in relation to its cover being made up of natural forests in preserved areas located at the UIRB head.

For the Latosol classification, losses of less than $10 \mathrm{tha}^{-1} \mathrm{yr}^{-1}$ can be seen in approximately $50 \%$ of its area of occurrence, as a result of its low erodibility, showing the intrinsic importance of

Table 5. Simulated soil loss intervals for current soil use in the UIRB.

\begin{tabular}{|c|c|c|}
\hline $\begin{array}{l}\text { Soil loss intervals } \\
\left(\mathrm{t} \mathrm{ha}^{-1} \mathrm{yr}^{-1}\right)\end{array}$ & Classification & Area $(\%)$ \\
\hline 0 to 2.5 & Slight & 23.52 \\
\hline 2.5 to 5 & Slight to moderate & 8.19 \\
\hline 5 to 10 & Moderate & 8.70 \\
\hline 10 to 15 & Moderate to high & 5.43 \\
\hline 15 to 25 & High & 7.55 \\
\hline 25 to 100 & Very high & 20.01 \\
\hline$>100$ & Extremely high & 26.60 \\
\hline
\end{tabular}


Table 6. Water erosion classification sorting as proposed by Beskow et al. (2009) and its distribution percentage by subbasin and soil type.

\begin{tabular}{|c|c|c|c|c|c|c|c|}
\hline \multirow[t]{2}{*}{ Sub-basin } & \multicolumn{7}{|c|}{$\begin{array}{l}\text { Distribution (\%) of the soil loss classifications } \\
\left(\mathrm{t} \mathrm{ha}^{-1} \mathrm{yr}^{-1}\right)\end{array}$} \\
\hline & 0 to 2.5 & 2.5 to 5 & 5 to 10 & 10 to 15 & 15 to 25 & 25 to 100 & $>100$ \\
\hline sub-1 & 67.59 & 2.39 & 3.53 & 2.48 & 3.20 & 8.35 & 12.47 \\
\hline sub-2 & 75.82 & 2.47 & 2.49 & 1.53 & 2.43 & 8.23 & 7.03 \\
\hline sub-3 & 20.40 & 12.35 & 12.26 & 7.19 & 9.75 & 22.89 & 15.16 \\
\hline sub-4 & 26.71 & 11.57 & 11.49 & 6.59 & 8.74 & 20.79 & 14.11 \\
\hline sub-5 & 24.36 & 10.07 & 10.42 & 6.10 & 8.16 & 20.81 & 20.08 \\
\hline sub-6 & 20.20 & 7.99 & 8.80 & 5.63 & 7.86 & 20.46 & 29.06 \\
\hline sub-7 & 18.49 & 7.28 & 7.84 & 5.09 & 7.29 & 20.53 & 33.48 \\
\hline
\end{tabular}

\begin{tabular}{|c|c|c|c|c|c|c|c|}
\hline \multirow[t]{2}{*}{ Soil } & \multicolumn{7}{|c|}{$\begin{array}{l}\text { Distribution (\%) of the soil loss classifications } \\
\qquad\left(\mathrm{t} \mathrm{ha}^{-1} \mathrm{yr}^{-1}\right)\end{array}$} \\
\hline & 0 to 2.5 & 2.5 to 5 & 5 to 10 & 10 to 15 & 15 to 25 & 25 to 100 & $>100$ \\
\hline Arg. & 24.39 & 8.56 & 7.94 & 5.79 & 9.10 & 35.79 & 8.43 \\
\hline Fluv. Neos. & 61.37 & 3.26 & 3.76 & 2.74 & 3.51 & 11.91 & 13.45 \\
\hline Camb. & 22.63 & 4.77 & 8.33 & 5.71 & 8.42 & 26.05 & 24.10 \\
\hline Latos. & 25.48 & 11.52 & 12.73 & 8.41 & 11.57 & 26.35 & 3.94 \\
\hline Lit. Neos. & 83.05 & 4.98 & 1.03 & 0.78 & 1.05 & 2.93 & 6.17 \\
\hline Organ. & 21.60 & 10.01 & 12.56 & 5.40 & 6.79 & 20.82 & 22.82 \\
\hline Gleys. & 21.15 & 7.93 & 7.43 & 4.69 & 7.36 & 20.50 & 30.94 \\
\hline
\end{tabular}

the physical attributes of this soil in relation to natural erosion vulnerability, as discussed by Oliveira et al. (2014). The other half can be found in the lowest areas of the basin and, therefore, in regions where there has been an accelerated occupation process and an alteration of the native cover, especially depending on the type of annual and perennial crops in this region, favoring the water erosion processes when not properly managed.

In relation to soil loss in the subbasins, it can be observed that subbasins 1 and 2, represented by locations P1 and P2, showed lower levels of water erosion since they are located in better preserved areas, characterized as being riverhead regions.

The values referring to sediment production, estimated in Equations 4, 5, 6, 7, 8, 9 and 10, are presented in Table 7 in terms of average annual value and in accordance with the classification proposed by Carvalho et al. (2000) and the sedimentometric rating curves that enable the calculation of sediment transportation, are presented in Figure 4.

The use of the sediment rating curve stems from the fact that the daily collection and analysis of samples is economically unviable, assuming that the discharge is a good predictor of the concentration of sediments, however, in certain cases, this technique has been seen to be imprecise with the degree of dispersion quite sharp (HICKS; GOMEZ; TRUSTRUM, 2004) and this is due to the fact that variables that influence the sediment transport process vary greatly in space and time. Nevertheless, as shown by Córdova and González (1997), the use of this technique is employed in larger basins since the variations between the daily average outflow maximums and minimums are not very significant.

On the other hand, Duvert et al. (2012) argue that the use of a rating curve for smaller basins is not recommended since it can lead to erroneous interpretations concerning the non-linearity and high dispersion among discharge and the concentration of sediments in suspension. In this context, Li et al. (2004) proposed the use of an erosion runoff index over the use of a rainfall erosivity index in order to estimate the solid discharge in basins of
Table 7. Sediment yield at the evaluated sedimentometric stations.

\begin{tabular}{|c|c|c|c|c|}
\hline Point & $\begin{array}{c}\text { Area } \\
\left(\mathrm{km}^{2}\right)\end{array}$ & Name & $\begin{array}{c}\text { Solid } \\
\text { Discharge } \\
\left(\mathrm{t} \mathrm{ha}^{-1} \text { year }^{-1}\right)\end{array}$ & Class \\
\hline P1 & 27 & $\begin{array}{l}\text { Jusante Aterro } \\
\text { Sanitário }\end{array}$ & 0.765 & Moderate \\
\hline P2 & 106 & Fazendinha & 0.469 & Low \\
\hline P3 & 385 & Pinhais & 0.413 & Low \\
\hline P4 & 808 & ETE-Sanepar & 5.124 & Very High \\
\hline P5 & 1160 & $\begin{array}{c}\text { Ponte do } \\
\text { Umbarazinho }\end{array}$ & 2.584 & High \\
\hline P6 & 2330 & Guajuvira & 0.923 & Moderate \\
\hline P7 & 2740 & Balsa Nova & 1.126 & Moderate \\
\hline
\end{tabular}

up to $200 \mathrm{~km}^{2}$, whileas for Duvert et al. (2010), the peak outflow represents a better answer for the estimation of this variable due to the fact that runoff characteristics translate the basin's behavior in a more efficient manner.

Thus, an alternative to circumvent these limitations is through the use of multivariable models that combine the physical and climatic characteristics, which may represent a better adjustment and understanding of the phenomenon, since the regression method traditionally used only broaches the topic of geographical relief physically described by the $\beta$ parameter.

Chella et al. (2005) evaluated sediment transportation in the Barigui River, which is a subbasin of the Upper Iguaçu River and found solid discharge values varying from 10 to $350 \mathrm{t} \mathrm{day}^{-1}$ in five monitored locations, classifying it as Moderate and High.

Knapik (2009) evaluated a water quality model using field data for the UIRB and found sediment concentration values varying from 100 a $176 \mathrm{mg} \mathrm{L}^{-1}$ at locations P5, P6 and P7, reaffirming that the values measured are inferior to the $500 \mathrm{mg} \mathrm{L}^{-1}$ limit in the CONAMA 375/05 classification. Likewise in this study, the observed values of sediment concentration varied from 
69.4 to $175.4 \mathrm{mg} \mathrm{L}^{-1}$ for the analyzed locations, indicating that although there exists a relative amount of anthropic occupation, the values are still within tolerable limits.

In this sense, the sediments are considered of great importance in the evaluation of water contamination levels, thanks not only to their capacity to accumulate metals, but also for transporting possible sources of contamination, which can release contaminant species (FROEHNER; MARTINS, 2008).

The suspended solid discharge yields of the UIRB varied from 0.47 to $5.124 \mathrm{t} \mathrm{ha}^{-1} \mathrm{yr}^{-1}$, at the inspected stations, and in accordance with the classification proposed by Carvalho et al. (2000), the basin presents sediment production varying from Low to High. Still, for the state of Paraná, Bollmann and Marques (2001) obtained solid discharge values for the Cachoeiras River Basin of the order of 3,6 tha-1 $\mathrm{yr}^{-1}$. Silva Júnior et al. (2011) evaluated the sediment production in the Mimoso River Basin in the state of Pernambuco, and found values varying from 0.91 to $10.91 \mathrm{tha}^{-1} \mathrm{yr}^{-1}$ in an area of $194.82 \mathrm{~km}^{2}$. Lima Neto, Wiegand and Araújo (2011) evaluated the total sediment production at $1.48 \mathrm{t} \mathrm{ha}^{-1} \mathrm{yr}^{-1}$ in a semi-arid Brazilian basin that has an area of $20,000 \mathrm{~km}^{2}$.

Considering the influence of the vegetational cover and the soil use, especially in locations where there is a strong presence of urbanization, it was observed that station 65013005 (ETE-SANEPAR), located downstream of the metropolitan region of Curitiba (MRC), showed an average value of $5.124 \mathrm{t} \mathrm{ha}^{-1} \mathrm{yr}^{-1}$, constituting the highest concentrated value for the UIRB. This value is similar to those found in the study performed by Chella et al. (2005), where values such as $0.6 \mathrm{tha}^{-1} \mathrm{yr}^{-1}$ were apparent in areas with lower degrees of anthropization and in areas where the urban nucleus belonging to the MRC exerted greater influence. These values were up to $4.57 \mathrm{tha}^{-1} \mathrm{yr}^{-1}$. In the referenced study, it can be seen that the highest sediment production rates occurred in sections where there exists a greater urban presence (subbasins 4 and 5), reaffirming the preponderant role of large urban centers in strengthening pollution loads.

In this sense, Scapin, Paiva and Beling (2007) characterize urbanized basins and apply various calculation methods in order to evaluate the transport of sediments in the city Santa Maria in the state of Rio Grande do Sul, finding an average value of $0.54 \mathrm{t} \mathrm{ha}^{-1} \mathrm{yr}^{-1}$. Although these values may be inferior to those found in this study for the MRC, it is important to consider that the urbanized area in the cited study is considerably smaller. This increase in the transportation of sediments in urban areas is due to the fact that there is an acceleration of runoff in the drainage networks that pass through cities, many of which, have been reground and had the roughness of the channel changed by the replacement of their banks and bottoms with concrete. Therefore, metropolitan regions do not produce erosion themselves but rather they increase the level of pollution in water courses, necessitating the need for mitigating actions to attenuate this process, especially during periods of extreme precipitation because, as demonstrated by Walling and Webb (1987), a very significant portion of sediment transportation occurs in sporadic periods.

Although the data used to construct the rating curve is derived from the ANA database and, thereby, presents a level of uncertainty, it can be seen that the data used had a good fit, principally for location $\mathrm{P} 4$, where the average estimated value was close to the average value observed in previous studies that had monitored the region's water currents.

These results have made it possible to estimate the SDR that was utilized to explain the spatial and temporal heterogeneity of the sediment transportation process and its interaction with precipitation as well as with the morphological characteristics of subbasins, in a similar manner in terms of methodology to the study performed by Wang, Yao and Liu (2008). By its own definition, the SDR is a scale factor used to accommodate average differences in sediment yield, having a value between 0 and 1 due to the deposition of sediments caused by changes in the discharge regime and storage tanks (WU et al., 2012).

With sediment production results and average basin erosion estimated through RUSLE, the average SDR was calculated for each subbasin (Figure 3 and Table 2), with the values being shown in Table 8 . It should be noted that the average value for the basin was 0.284 , meaning that $28.4 \%$ of the generated soil loss was transported to the control section, resulting in similarities to the findings of Chaves (2010) who studies the Pipiripau River Basin and found an average value of 0.24 . Nevertheless, this same author noted a significant variation in the values found as a result of the methodology adopted in order to estimate the SRD, as well as a result of the rating curves. This reaffirms that, in this context, a continuous surveillance program allows the acquisition of a larger universe of data, resulting in more precise adjustments due to the quality of the data collected.

The values calculated for the UIRB vary in dimension between subbasins of 6.6 to $88.3 \%$ (Table 8 ). This spatial variability has been observed in other studies, like that of De Vente et al. (2008), who obtained a SDR that varied from 0.03 to $55 \%$ for in 61 subbasins in Spain. Likewise, Van Rompaey, Krasa and Dostal (2007) calculated the SDR of a basin of $1.960 \mathrm{~km}^{2}$ in the Czech Republic, acquiring a value of $28 \%$; Verstraeten, Prosser and Fogarty (2007) reported SDR values of 20 to $39 \%$ for basins from 167 to 2,173 $\mathrm{km}^{2}$ in Australia; Fryirs and Brierley (2001) estimated a SDR of nearly $70 \%$ in the Bega River Basin in the Australian state of New South Wales, which caused dramatic changes in the fluvial geomorphology and Alatorre et al. (2012) determined a SDR of approximately $5 \%$ for an experimental basin of $2.84 \mathrm{~km}^{2}$ in Spain.

In terms of the sediment delivery rate in Brazil, Silva and Schulz (2007) evaluated the hydrosedimentological dynamic in the Água Fria River Basin in the city Palmas in the state of Tocantins from the period of February 1998 until January 1999 and acquired the average SDR value of $6.2 \%$. Silva, Santos and Silva (2014) found a SDR of $8 \%$ for the Tapacurá River Basin in the state of Pernambuco with an area of $470 \mathrm{~km}^{2}$. On the other

Table 8. Sediment delivery rate calculated for the UIRB by subbasin.

\begin{tabular}{cccc}
\hline Subbasin & $\mathbf{Y}\left(\mathbf{t ~ h a}^{-1} \mathbf{y e a r}^{-1}\right)$ & $\mathbf{E}\left(\mathbf{t ~ h a}^{\mathbf{- 1}} \mathbf{y e a r}^{-\mathbf{1}}\right)$ & $\mathbf{S D R}$ \\
\hline sub-1 & 0.765 & 3.47 & 0.220 \\
sub-2 & 0.469 & 2.63 & 0.178 \\
sub-3 & 0.413 & 6.29 & 0.066 \\
sub-4 & 5.124 & 5.80 & 0.883 \\
sub-5 & 2.584 & 6.60 & 0.392 \\
sub-6 & 0.923 & 7.77 & 0.119 \\
sub-7 & 1.126 & 8.36 & 0.135 \\
\hline
\end{tabular}


hand, Beskow et al. (2009), examining the Rio Grande River Basin in the state of Minas Gerais, found an average value of $1.62 \%$ for a drainage area greater than $6,000 \mathrm{~km}^{2}$, whereas Durães, Mello and Beskow (2016), upon inspection of the Paraopeba River Basin's SDR, discovered values varying from $8.6 \%$ to $66 \%$ for an area of $8,659 \mathrm{~km}^{2}$.

In accordance with Brown et al. (2005), the impacts of alterations in the use of soil in drainage basins concerning superficial runoff can, in general, be evaluated in terms of maximum and minimum outflow. However, these effects are associated with processes caused by water erosion, since within the hydroseimentological cycle context, water erosion leads to soil volume diminution, which results in a lower water holding capacity.

The results found here show that alterations in soil coverage and usage can significantly affect the hydrological dynamic of drainage basins in terms of surface runoff. This alteration of the runoff can lead to a higher rate of sediment transportation as a result of the upstream erosion process with consequences in the diminution of humidity variability in deep soil layers and the replenishment of aquifers, which results in a reduction of discharge during periods of drought and an increase during rainy periods as a result of the alterations in the water infiltration rates of the soil.

\section{CONCLUSION}

The use of the RUSLE model associated with GIS through Map Algebra proved to be an effective tool in determining the water erosion vulnerability of drainage basin soil, allowing for the identification of more vulnerable areas.

The Gleysol classification showed the highest potential rates of water erosion above $25 \mathrm{t} \mathrm{ha}^{-1} \mathrm{yr}^{-1}$, corresponding to $51.44 \%$ of all occurrences, followed by Cambisol (50.15\%), Argisol (44.22\%) and Organosol (43.64\%).

Subbasins 4 and 5, located downstream from the Curitiba metropolitan region, presented greater rates of sediment production and sediment transportation, showing the preponderant role of large urban centers in strengthening pollution loads in river courses.

The SDR varies spatially in the UIRB as a result of soil coverage, just like topographical features, which tend to prefer sedimentation processes in areas with lower slopes, since they favor this phenomenon.

Considering the spatial and temporal variation of the suspended solids data, the methodology used has proven an important tool in terms of practices, despite inherent limitations, and makes continued research of the UIRB necessary, which would enable a greater and more representative studies.

\section{REFERENCES}

ALATORRE, L. C.; BEGUERÍA, S.; LANA-RENAULT, N.; NAVAS, A.; GARCÍA-RUIZ, J. M. Soil erosion and sediment delivery in a mountain catchment under scenarios of land use change using a spatially distributed numerical model. Hydrology and Earth System Sciences, v. 16, n. 5, p. 1321-1334, 2012. http:// dx.doi.org/10.5194/hess-16-1321-2012.
ARAÚJO, F. S.; SALVIANO, A. C.; HOLANDA NETO, M. R. Estimativa da erodibilidade de latossolos do Piaú. Scientia Plena, v. 7, p. 1-6, 2011.

ARNOLD, J. G.; SRINIVASAN, R.; MUTTIAH, R. S.; WILLIAMS, $\mathrm{J}$. R. Large area hydrologic modeling and assessment part I: model development. Journal of the American Water Resources Association, v. 34, n. 1, p. 73-89, 1998. http://dx.doi.org/10.1111/j.1752-1688.1998. tb05961.x.

AVANZI, J. C.; SILVA, M. L. N. S.; CURI, N.; NORTON, L. D.; BESKOW, S.; MARTINS, S. G. Spatial distribution of water erosion risk in a watershed with eucalyptus and Atlantic forest. Ciência e Agrotecnologia, v. 37, n. 5, p. 427-434, 2013. http://dx.doi. org/10.1590/S1413-70542013000500006.

BATALHA, R. M. P. Expectativa de risco de degradação dos recursos bidricos na bacia do rio Jundiaí-Mirim. 2006. 96 f. Dissertação (Mestrado em Engenharia Agrícola)-Faculdade de Engenharia Agrícola, Universidade Estadual de Campinas, Campinas, 2006.

BERTONI, J.; LOMBARDI NETO, F. L. Conservação do solo. 5th ed. São Paulo: Ícone, 2005.

BESKOW, S.; MELLO, C. R.; NORTON, L. D.; CURI, N.; VIOLA, M. R.; AVANZI, J. C. Soil erosion prediction in the Grande river basin, Brazil using distributed modeling. Catena, v. 79, n. 1, p. 49-59, 2009. http://dx.doi.org/10.1016/j.catena.2009.05.010.

BOLLMANN, H. A.; MARQUES, D. M. Gestão ambiental integrada de bacias hidrográficas: Bacia do Rio Cachoeiras - São Mateus do Sul - PR. Revista Brasileira de Recursos Hidricos, v. 6, n. 3, p. 45-65, 2001. http://dx.doi.org/10.21168/rbrh.v6n3.p45-65.

BORGES, K. M. R.; CARVALHO JÚNIOR, A. O.; MARTINS, E. S.; GOMES, R. A. T.; GUIMARÃES, R. F. Vulnerabilidade natural: a perda de solo da bacia do rio Carinhanha (MG/BA) usando uma abordagem qualitativa da equação universal de perda de solos. Geographia., v. 14, p. 101-125, 2012.

BROWN, A. E.; ZHANG, L.; MCMAHON, T. A.; WESTERN, A. W.; VERTESSY, R. A. A review of paired catchment studies for determining changes in water yield resulting from alterations in vegetation. Journal of Hydrology, v. 310, n. 1-4, p. 28-61, 2005. http://dx.doi.org/10.1016/j.jhydrol.2004.12.010.

CARVALHO, N. O.; FILIZOLA JÚNIOR, N. P.; SANTOS, P. M.; LIMA, J. E. F. W. Guia de práticas sedimentológicas. Brasília: ANEEL, 2000.

CASTRO, W. J.; LEMKE-DE-CASTRO, M. L.; LIMA, J. O.; OLIVEIRA, L. F. C.; RODRIGUES, C.; FIGUEIREDO, C. C. Erodibilidade de solos do cerrado goiano. Revista em Agronegócio e Meio Ambiente, v. 4, n. 2, p. 305-320, 2011.

CHAVES, H. M. L. Relações de aporte de sedimento e implicações de sua utilização no pagamento por serviço ambiental em bacias 
hidrográficas. Revista Brasileira de Ciência do Solo, v. 34, n. 4, p. 1469 1477, 2010. http://dx.doi.org/10.1590/S0100-06832010000400043.

CHELLA, M. R.; FERNANDES, V. S.; FERMIANO, G. A.; FILL, H. D.; SANTOS, I. Avaliação do transporte de sedimentos no rio Barigui. Revista Brasileira de Recursos Hídricos, v. 10, n. 3, p. 105-111, 2005. http://dx.doi.org/10.21168/rbrh.v10n3.p105-111.

CÓRDOVA, J. R.; GONZÁLEZ, M. Sediment yield estimation in small watersheds based on streamflow and suspended sediment discharge measurements. Soil Technology, v. 11, n. 1, p. 57-65, 1997. http://dx.doi.org/10.1016/S0933-3630(96)00115-8.

DE VENTE, J.; POESEN, J.; VERSTRAETEN, G.; VAN ROMPAEY, A.; GOVERS, G. Spatially distributed modelling of soil erosion and sediment yield at regional scales in Spain. Global and Planetary Change, v. 60, n. 3-4, p. 393-415, 2008. http:/ /dx.doi. org/10.1016/j.gloplacha.2007.05.002.

DURÃES, M. F.; MELLO, C. R. Hydrosedimentologic disturbance index applied to watersheds of Minas Gerais State. Ciência e Agrotecnologia, v. 38, n. 1, p. 61-67, 2014. http://dx.doi.org/10.1590/ S1413-70542014000100007.

DURÃES, M. F.; MELLO, C. R.; BESKOW, S. Sediment yield in Paraopeba river basin - MG, Brazil. International Journal of River Basin Management, 2016. In press.

DUVERT, C.; GRATIOT, N.; EVRARD, O.; NAVRATIL, O.; NÉMERY, J.; PRAT, C.; ESTEVES, M. Drivers of erosion and suspended sediment transport in three headwater catchments of the Mexican Central Highlands. Geomorphology, v. 123, n. 3-4, p. 243-256, 2010. http://dx.doi.org/10.1016/j.geomorph.2010.07.016.

DUVERT, C.; NORD, G.; GRATIOT, N.; NAVRATIL, O.; NADAL-ROMERO, E.; MATHYS, N.; NÈMERY, J.; REGUES, D.; GARCIA-RUIZ, J. M.; GALLART, F.; ESTEVES, M. Towards prediction of suspended sediment yield from peak discharge in small erodible mountains catchments $(0.45-22 \mathrm{~km} 2)$ of France, Mexico and Spain. Journal of Hydrology, v. 454-455, p. 42-55, 2012. http://dx.doi.org/10.1016/j.jhydrol.2012.05.048.

ESRI - ENVIRONMENTAL SYSTEMS RESEARCH INSTITUTE. ArcGIS: getting started with ArcGIS. Redlands, 2004.

FROEHNER, S.; MARTINS, R. F. Avaliação da composição química de sedimentos do rio Barigui na região metropolitana de Curitiba. Quimica Nova, v. 31, n. 8, p. 2020-2026, 2008. http:// dx.doi.org/10.1590/S0100-40422008000800020.

FRYIRS, K.; BRIERLEY, G. J. Variability in sediment delivery and storage along river courses in Bega catchment, NSW, Australia: implications for geomorphic river recovery. Geomorphology, v. 38, n. 3-4, p. 237-265, 2001. http://dx.doi.org/10.1016/S0169$555 \mathrm{X}(00) 00093-3$.

GASSMAN, P. W.; REYES, M. R.; GREEN, C. H.; ARNOLD, J. G. The soil and water assessment tool: historical development, applications, and future research directions. Transactions of the $A S A B E$, v. 50, n. 4, p. 1211-1250, 2007. http://dx.doi. org/10.13031/2013.23637.

GUERRERO, M.; NONES, M.; SAURRAL, R.; MONTROULL, N.; SZUPIANY, R. N. Parana river morphodynamics in the contexto of climate change. International Journal of River Basin Management, v. 11, n. 4, p. 423-437, 2013. http://dx.doi.org/10.1080/157151 24.2013.826234.

HICKS, D.; GOMEZ, B.; TRUSTRUM, N. A. Event suspended sediment characteristics and the generation of hyperpycnal plumes at river mouths: east coast continental margin, North Island, New Zealand. The Journal of Geology, v. 112, n. 4, p. 471-485, 2004. http:// dx.doi.org/10.1086/421075.

HOYOS, N.; WAYLEN, P. R.; JARAMILLO, A. Seasonal and spatial patterns of erosivity in a tropical watershed of the Colombian Andes. Journal of Hydrology, v. 314, n. 1-4, p. 177-191, 2005. http:// dx.doi.org/10.1016/j.jhydrol.2005.03.014.

HUI, L.; XIAOLING, C.; LIM, K. J.; XIAOBIN, C.; SAGONG, M. Assessment of soil erosion and sediment yield in Liao watershed, Jiangxi province, China, using USLE, GIS and RS. Journal of Earth Science, v. 21, n. 6, p. 941-953, 2010. http://dx.doi.org/10.1007/ s12583-010-0147-4.

KNAPIK, H. G. Reflexões sobre monitoramento, modelagem e calibração na gestão de recursos hídricos: estudo de caso da qualidade da água da bacia do Alto Iguaçu. 2009. 197 f. Dissertação (Mestrado em Engenharia de Recursos Hídricos e Ambiental)-Setor de Tecnologia, Universidade Federal do Paraná, Curitiba, 2009.

KNAPIK, H.; FERNANDES, C.; PICKBRENNER, K.; PORTO, M.; BASSANESI, K. Qualidade da água da bacia do rio Iguaçu: diferenças conceituais entre os modelos QUAL2E e QUAL2K. Revista Brasileira de Recursos Hidricos, v. 16, n. 2, p. 75-88, 2011. http://dx.doi.org/10.21168/rbrh.v16n2.p75-88.

LEE, G.; LEE, K. Determing the sediment delivery ratio using the sediment-rating curve and a geographical information system-embedded soil erosion modelo $\mathrm{n}$ a basin scale. Journal of Hydrologic Engineering, v. 15, n. 10, p. 834-843, 2010. http://dx.doi. org/10.1061/(ASCE)HE.1943-5584.0000254.

LI, Z.; LI, P.; LU, K.; ZHENG, L.; GUO, Y. Development and application of the runoff erosivity for sediment yield prediction on watershed scale. In: INTERNATIONAL SOIL CONSERVATION ORGANIZATION (ISCO) CONFERENCE, 13., 2004, Brisbane. Proceedings... Tucson: USDA, 2004. Paper 668.

LIMA NETO, I. E.; WIEGAND, M. C.; ARAÚJO, J. C. Sediment redistribution due to a dense reservoir network in a large semi-arid Brazilian basin. Hydrological Sciences Journal, v. 56, n. 2, p. 319-333, 2011. http://dx.doi.org/10.1080/02626667.2011.553616.

MANNIGEL, A. R.; CARVALHO, M. P.; MORETTI, D.; MEDEIROS, L. R. Fator erodibilidade e tolerância de perda dos 
solos do Estado de São Paulo. Acta Scientiarum: Agronomy, v. 24, p. 1335-1340, 2002. http://dx.doi.org/10.4025/actasciagron. v24i0.2374.

MARQUES, J. J. G. S. M.; CURI, N.; FERREIRA, M. M.; LIMA, J. M.; SILVA, M. L. N.; SÁ, M. A. C. Adequação de métodos indiretos para estimativa da erodibilidade de solos com horizonte B textural no Brasil. Revista Brasileira de Ciência do Solo, v. 21, n. 3, p. 447-456, 1997. http://dx.doi.org/10.1590/S0100-06831997000300014.

MARTINS, S. G.; SILVA, M. L. N.; AVANZI, J. C.; CURI, N.; FONSECA, S. Fator cobertura e manejo dos solos e perdas de solo e água em cultivo de eucalipto e em mata atlântica nos tabuleiros costeiros do estado do Espírito Santo. Scientia Forestalis, v. 38, n. 87 , p. 517-526, 2010.

MELLO, C. R.; ÁVILA, L. F.; VIOLA, M. R.; CURI, N.; NORTON, L. D. Assessing the climate change impacts on the rainfall erosivity throughout the twenty-first centtury in the Grande River Basin (GRB) headwaters, Southeastern Brazil. Environmental Earth Sciences, v. 73, n. 12, p. 8683-8698, 2015. http://dx.doi.org/10.1007/ s12665-015-4033-3.

MELLO, C. R.; VIOLA, M. R.; BESKOW, S.; NORTON, L. D. Multivariate models for annual rainfall erosivity in Brazil. Geoderma, v. 202-203, p. 88-102, 2013. http://dx.doi.org/10.1016/j. geoderma.2013.03.009.

MOORE, I. D.; BURCH, G. J. Modeling erosion and deposition: Topographic effects. Transactions of the AS AE. American Society of Agricultural Engineers, v. 29, n. 6, p. 1624-1640, 1986. http://dx.doi. org/10.13031/2013.30363.

NEARING, M. A.; LANE, L. J.; LOPES, V. L. Modeling soil erosion. In: LAL, R. (Ed.). Soil erosion: research methods. Delray Beach: St. Lucie Press, 1994. p. 127-135.

NEL, W.; REYNHARDT, D. A.; SUMMER, P. D. Effect of altitude on erosive characteristics of concurrent rainfall events in the northern Kwazulu-Natal Drakensberg. Water S.A., v. 36, n. 4, p. 509-512, 2010. http://dx.doi.org/10.4314/wsa.v36i4.58429.

OLIVEIRA, V. A.; MELLO, C. R.; DURÃES, M. F.; SILVA, A. M. Soil erosion vulnerability in the Verde river basin, Southern Minas Gerais. Ciência e Agrotecnologia, v. 38, n. 3, p. 262-269, 2014. http://dx.doi.org/10.1590/S1413-70542014000300006.

PANDEY, A.; CHOWDARY, V. M.; MAL, B. C. Identification of critical erosion prone áreas in the small agricultural watershed using USLE, GIS and remote sensing. Water Resources Management, v. 21, n. 4, p. 729-746, 2007. http://dx.doi.org/10.1007/s11269006-9061-z.

PRADHAN, B.; CHAUDHARI, A.; ADINARAYANA, J.; BUCHROITHNER, M. F. Soil erosion assessment and its correlation with landslide events using remote sensing data and GIS: a case study at Penang Island, Malaysia. Environmental
Monitoring and Assessment, v. 184, n. 2, p. 715-727, 2012. http:// dx.doi.org/10.1007/s10661-011-1996-8. PMid:21509515.

RENARD, K. G.; FOSTER, G. R.; WEESIES, G. A.; PORTER, P. J. RUSLE: revised universal soil loss equation. Journal of Soil and Water Conservation, v. 46, p. 30-33, 1991.

RIBEIRO, L. S.; ALVES, M. G. Análise de susceptibilidade à erosão laminar no município de Campos dos Goytacazes/RJ através de técnicas de geoprocessamento. Estudios Geograficos, v. 6, n. 1, p. 89-100, 2008.

RUHOFF, A. L.; SOUZA, B. S. P.; GIOTTO, E.; PEREIRA, R. S. Avaliação dos processos erosivos através da equação universal de perda de solos, implementada com algoritmos em LEGAL. Geomática, v. 1, p. 12-22, 2006.

SÁ, M. A. C.; LIMA, J. M.; CURI, N.; MASSAROTO, J. A.; MARQUES, J. J. G. S. M. Estimativa da erodibilidade pela desagregação por ultra-som e atributos de solos com horizonte B textural. Pesquisa Agropecuária Brasileira, v. 39, n. 7, p. 691-699, 2004. http://dx.doi.org/10.1590/S0100-204X2004000700011.

SCAPIN, J.; PAIVA, J. B. D.; BELING, F. A. Avaliação de métodos de cálculo do transporte de sedimentos em um pequeno rio urbano. Revista Brasileira de Recursos Hídricos, v. 12, n. 4, p. 5-21, 2007. http:/ / dx.doi.org/10.21168/rbrh.v12n4.p5-21.

SILVA JÚNIOR, V. P.; MONTENEGRO, A. A. A.; SILVA, T. P. N.; GUERRA, S. M. S.; SANTOS, E. S. Produção de água e sedimentos em bacia representativa do semiárido pernambucano. Revista Brasileira de Engenharia Agricola e Ambiental, v. 15, n. 10, p. 1073 1081, 2011. http://dx.doi.org/10.1590/S1415-43662011001000012.

SILVA, A. M.; ALVARES, C. A. Levantamento de informações e estruturação de um banco de dados sobre a erodibilidade de classes no estado de São Paulo. Geociências, v. 24, p. 33-41, 2005.

SILVA, A. M.; SCHULZ, H. E. Hydrosedimentological dynamic on Água Fria watershed. Brazilian Archives of Biology and Technology, v. 50, n. 5, p. 861-870, 2007. http://dx.doi.org/10.1590/S151689132007000500014 .

SILVA, A. M.; SILVA, M. L. N.; CURI, N.; AVANZI, J. C.; FERREIRA, M. M. Erosividade da chuva e erodibilidade de Cambissolo e Latossolo na região de Lavras, sul de Minas Gerais. Revista Brasileira de Ciencia do Solo, v. 33, n. 6, p. 1811-1820, 2009. http://dx.doi.org/10.1590/S0100-06832009000600029.

SILVA, F. M.; LERMEN, V. K.; NERY, J. T. Variabilidade interanual da precipitação na bacia do rio Iguaçu. Acta Scientiarum, v. 23, n. 6, p. 1439-1444, 2001.

SILVA, R. M.; MONTENEGRO, S. M. G. L.; SANTOS, C. A. G. Integration of GIS and remote sensing for estimation of soil loss and prioritization of critical sub-catchments: a case study of Tapacurá catchment. Natural Hazards, v. 62, n. 3, p. 953-970, 2012. http://dx.doi.org/10.1007/s11069-012-0128-2. 
SILVA, R. M.; SANTOS, C. A. G.; SILVA, A. M. Predicting soil erosion and sediment yield in the Tapacurá catchment, Brazil. Journal of Urban and Environmental Engineering, v. 8, n. 1, p. 75-82, 2014. http://dx.doi.org/10.4090/juee.2014.v8n1.075082.

SILVA, V. Estimativa da erosão atual da bacia do rio Paracatu (MG/ GO/DF). Pesquisa Agropecuária Tropical, v. 34, p. 147-159, 2004.

\section{SUDERHSA - SISTEMA DE INFORMAÇÕES GEOGRÁFICAS} PARA GESTÃO DE RECURSOS HÍDRICOS NO ALTO IGUAÇU. Relatório final. Curitiba, 2004.

VAN ROMPAEY, A.; KRASA, J.; DOSTAL, T. Modelling the impact of land cover changes in the Czech Republic on sediment delivery. Land Use Policy, v. 24, n. 3, p. 576-583, 2007. http:/ /dx.doi. org/10.1016/j.landusepol.2005.10.003.

VEMU, S.; PINNAMANENI, U. B. Estimation of spatial patterns of soil erosion using remote sensing and GIS: a case study of Indravati cachtment. Natural Hazards, v. 59, n. 3, p. 1299-1315, 2011. http://dx.doi.org/10.1007/s11069-011-9832-6.

VERSTRAETEN, G.; PROSSER, I. P.; FOGARTY, P. Predicting the spatial patterns of hillslope sediment delivery to river channels in the Murrumbidgee catchment, Australia. Journal of Hydrology, v. 334, n. 3-4, p. 440-454, 2007. http://dx.doi.org/10.1016/j. jhydrol.2006.10.025.

WALLING, D. E. The sediment delivery problem. Journal of Hydrology, v. 65, n. 1-3, p. 209-237, 1983. http://dx.doi.org/10.1016/00221694(83)90217-2.

WALLING, D. E.; WEBB, B. W. Material transport by the world's rivers: evolving perspectives. In: RODDA, J. C.; MATALAS, N. C. Water for the future: hydrology in perspective. Proceedings of the Rome Symposium. Wallingford: IAHS, 1987. p. 313-329.

WANG, G. Q.; HAPUARACHCHI, H.; ISHIDAIRA, H.; KIEM, A. S.; TAKEUCHI, K. Estimation of soil erosion and sediment yield during individual rainstorms at catchment scale. Water Resources Management, v. 23, n. 8, p. 1447-1465, 2009. http://dx.doi. org/10.1007/s11269-008-9335-8.
WANG, L. L.; YAO, W. Y.; LIU, Y. L. China's research progress in sediment delivery ratio of watershed. Yellow River, v. 30, p. 36-45, 2008.

WISCHMEIER, W. H.; SMITH, D. D. Predicting rainfall erosion losses: a guide to conservation planning. Washington: U.S. Department of Agriculture, Science and Education Administration, 1978. (Agricultural Handbook, 537).

WU, L.; LONG, T. Y.; LIU, X.; MMEREKI, D. Simulation of soil loss processes based on rainfall runoff and the time factor of governance in the Jialing river watershed, China. Environmental Monitoring and Assessment, v. 184, n. 6, p. 3731-3748, 2012. http:// dx.doi.org/10.1007/s10661-011-2220-6. PMid:21755426.

XAVIER, A. P.; SILVA, A. M.; SILVA, R. M. Mudanças espaçotemporais da variabilidade da precipitação e perdas de solo na bacia do rio Mamuaba, Brasil. Cadernos do Logepa, v. 8, p. 79-102, 2013.

YANG, C. T. Unit stream power equation for gravel. Journal of Hydrology, v. 110, p. 1783-1797, 1984.

ZHANG, H.; YANG, Q.; LI, R.; LIU, Q.; MOORE, D.; HE, P.; RITSEMA, C. J.; GEISSEN, V. Extension of a GIS procedure for calculating the RUSLE equation LS factor. Computers \& Geosciences, v. 52, p. 177-188, 2013. http://dx.doi.org/10.1016/j. cageo.2012.09.027.

\section{Authors contributions}

Matheus Fonseca Durães: Paper conception, research, data analysis, literature review, discussion and paper writing.

José Alexandre Pinto Coelho Filho: contributed on paper revision, design of the maps, and results discussion.

Vinícius Augusto de Oliveira: contributed on paper revision, literature review and paper formatting. 